\title{
Role of DNA Ligase in the Repair of Single Strand Breaks Induced in DNA by Mild Heating of Escherichia coli
}

\author{
By C. PAULING AND L. A. BECK \\ Department of Biology, University of California, \\ Riverside, California 92502, U.S.A. \\ (Received 30 July i974; revised I8 October 1974) \\ INTRODUCTION
}

Bridges, Ashwood-Smith \& Munson (I969a, $b$ ) and Matsumoto \& Kagami-Ishi (1970) have reported a general correlation between sensitivity to mild $\left(52{ }^{\circ} \mathrm{C}\right)$ heat and to ionizing radiation among several strains of Escherichia coli, and Bridges et al. (1969b) and Sedgwick \& Bridges (1972) have demonstrated the production of single strand breaks in the bacterial DNA as a consequence of heating. Sedgwick \& Bridges (1972) examined the introduction by heating of single strand breaks of DNA or E. coli strains carrying mutations at polA which affect DNA polymerase I, an important component in the repair of DNA (Town, Smith \& Kaplan, I97I). Whereas $\mathrm{pol}^{+}$and polA derivatives of E. coli KI 2 showed a similar pattern of single strand breaks in DNA upon heating at $52{ }^{\circ} \mathrm{C}$, derivatives of E. coli B carrying res $^{+}$and res $A$ alleles (Kato \& Kondo, I970) were both insensitive to the introduction of strand breaks by this treatment. Accordingly, Sedgwick \& Bridges (I972) concluded that the introduction of single strand breaks in DNA as a result of heating is the consequence of strain-specific characteristics such as nucleases rather than a direct physical effect of heat on DNA.

The correlation between sensitivity to heat and to ionizing radiation suggests that radiation repair processes play an important role in survival after exposure to $52{ }^{\circ} \mathrm{C}$. The demonstration that single strand breaks occur in DNA following heating implies that the ability of the cells to repair such breaks is a necessary condition for survival. If the repair of single strand breaks in DNA is important in survival after mild heating, we would predict that a DNA-ligase-defective mutant (Pauling \& Hamm, I968, 1969; Dean and Pauling, 1970) should be more sensitive than the wild-type strain, and that such breaks should accumulate in the DNA of the mutant more rapidly than in the wild-type strain during heating.

\section{METHODS}

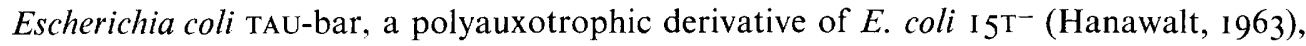
and ts-7, a temperature-sensitive, DNA-ligase-defective derivative of TAU-bar (Pauling \& Hamm, 1968), were cultured aerobically in a glucose-salts minimal medium with appropriate supplements as previously described (Deutch \& Pauling, I97I). Media transfers were accomplished by centrifugation. Viable counts were determined by plating appropriate dilutions on an enriched medium as previously described (Deutch \& Pauling, 1971).

Logarithmic-phase cultures ( $\mathrm{IO} \mathrm{ml}$ ) were grown at $25^{\circ} \mathrm{C}$ to a density of $\mathrm{I} \times 10^{8}$ bacteria $/ \mathrm{ml}$ in minimal medium supplemented with required growth factors including $0.5 \mu \mathrm{g}$ thymine $/ \mathrm{ml}$ and either $200 \mu \mathrm{Ci}$ [methyl- ${ }^{3} \mathrm{H}$ ] thymine (New England Nuclear; Io $\mathrm{Ci} / \mathrm{mmol}$ ) or Io $\mu \mathrm{Ci}$ $\left[2-{ }^{14} \mathrm{C}\right]$ thymine (Schwarz-Mann; $56 \mathrm{mCi} / \mathrm{mmol}$ ). The cultures were harvested, washed with 
unsupplemented minimal medium, and resuspended in an equal volume of fresh medium. Appropriate growth factors were added, and volumes of each culture were incubated at 25, 46 and $52{ }^{\circ} \mathrm{C}$ for $20 \mathrm{~min}$.

Samples were removed and the DNA was assayed for single strand breaks by zone sedimentation through alkaline sucrose density gradients using a modification (Kato \& Kondo, I970; Sedgwick \& Bridges, 1972) of the method of McGrath \& Williams (1966). After sampling, ${ }^{3} \mathrm{H}$-labelled ts-7 cells and ${ }^{14} \mathrm{C}$-labelled TAU-bar cells were mixed together, and $0.3 \mathrm{ml}$ of the mixed cell suspension was added to $0.6 \mathrm{ml}$ of a solution containing $\mathrm{I} \%$ $(\mathrm{w} / \mathrm{v}$ ) sodium dodecyl sulphate, $0.25 \mathrm{~N}-\mathrm{NaOH}, 0.005 \mathrm{M}-\mathrm{EDTA}, 0.05 \mathrm{M}-\mathrm{NaCl}$, and $0.005 \mathrm{M}-$ tris(hydroxymethyl)-aminomethane (Trizma Base; Sigma) that had been previously layered on to the top of a $36 \mathrm{ml} 5$ to $20 \%$ linear sucrose density gradient containing $0 \cdot 1 \mathrm{~N}-\mathrm{NaOH}$, $0.9 \mathrm{M}-\mathrm{NaCl}$, and $0.00 \mathrm{I} \mathrm{M-EDTA,} \mathrm{pH} \mathrm{II} .5$. A period of $20 \mathrm{~min}$ was allowed for lysis, then the gradients were centrifuged in an SW-27 rotor in a Beckman L2-65B centrifuge at $27000 \mathrm{rev} / \mathrm{min}$ for $2 \mathrm{~h}$ at $20^{\circ} \mathrm{C}$. Ten-drop fractions were collected from the bottom of the centrifuge tube and were assayed for radioactivity as previously described (Pauling \& Hamm, I968). Acid-soluble material was assayed for radioactivity as previously described (Pauling \& Hamm, 1968).

\section{RESULTS AND DISCUSSION}

The DNA-ligase-defective mutant ts-7 proved to be markedly more sensitive to heating at $52{ }^{\circ} \mathrm{C}$ than strain TAU-bar. After $20 \mathrm{~min}$ incubation at $52{ }^{\circ} \mathrm{C}, 3 \mathrm{I} \%$ of TAU-bar bacteria remained viable, whereas only $0.1 \mathrm{I} \%$ of ts- 7 cells survived.

Prelabelled DNA was assayed for single strand breaks by zone sedimentation following lysis of the bacterial cells directly on alkaline sucrose density gradients. This procedure eliminated the need for pipetting the lysate, thus minimizing shear effects. The general experimental procedure entailed prelabelling TAU-bar DNA with $\left[{ }^{14} \mathrm{C}\right]$ thymine and ts- 7 DNA with $\left[{ }^{3} \mathrm{H}\right]$ thymine during growth at $25{ }^{\circ} \mathrm{C}$, the permissive temperature for ts- 7 . The cultures were transferred to fresh media without radioisotopes and, following the addition of appropriate supplements, were incubated at the desired temperature. Figure I presents sedimentation profiles for DNA isolated from TAU-bar and ts- 7 after 20 min incubation at (a) $25{ }^{\circ} \mathrm{C},(b) 46^{\circ} \mathrm{C}$, and $(c) 52{ }^{\circ} \mathrm{C}$. The profiles obtained after 20 min growth at $25^{\circ} \mathrm{C}$ for TAU-bar and ts- 7 are superimposable, indicating that after growth at $25^{\circ} \mathrm{C}$ there are no more single strand breaks in ts-7 DNA than in TAU-bar DNA. However, 20 min incubation at $46{ }^{\circ} \mathrm{C}$ results in some breakage, and at $52{ }^{\circ} \mathrm{C}$ in substantial breakage, of ts- 7 DNA but not of TAU-bar DNA.

The introduction of single strand breaks into ts- 7 DNA as a consequence of heating at $52{ }^{\circ} \mathrm{C}$ suggests that the resulting ends of polynucleotide strands may be degraded by exonucleases. We have examined the release of radioactivity to the acid-soluble fraction, and found that after $20 \mathrm{~min}$ at $52{ }^{\circ} \mathrm{C}, 10.5 \%$ of the radioactivity in ts- 7 DNA was rendered acid-soluble, whereas only $\mathrm{I} \cdot 3 \%$ of the radioactivity in TAU-bar DNA became acid-soluble. Thus, the production of single strand breaks in ts-7 DNA is accompanied by degradation of the DNA.

These results indicate that repair of single strand breaks is an important parameter in promoting survival after heating to $52{ }^{\circ} \mathrm{C}$. Strain TAU-bar does not show such breaks after 20 min at $52{ }^{\circ} \mathrm{C}$, whereas its DNA-ligase-defective derivative, ts-7, that is markedly more sensitive to heating than TAU-bar, shows substantial breakage. Two possible explanations are apparent: firstly, that heating introduces single strand breaks in both strains, and that 


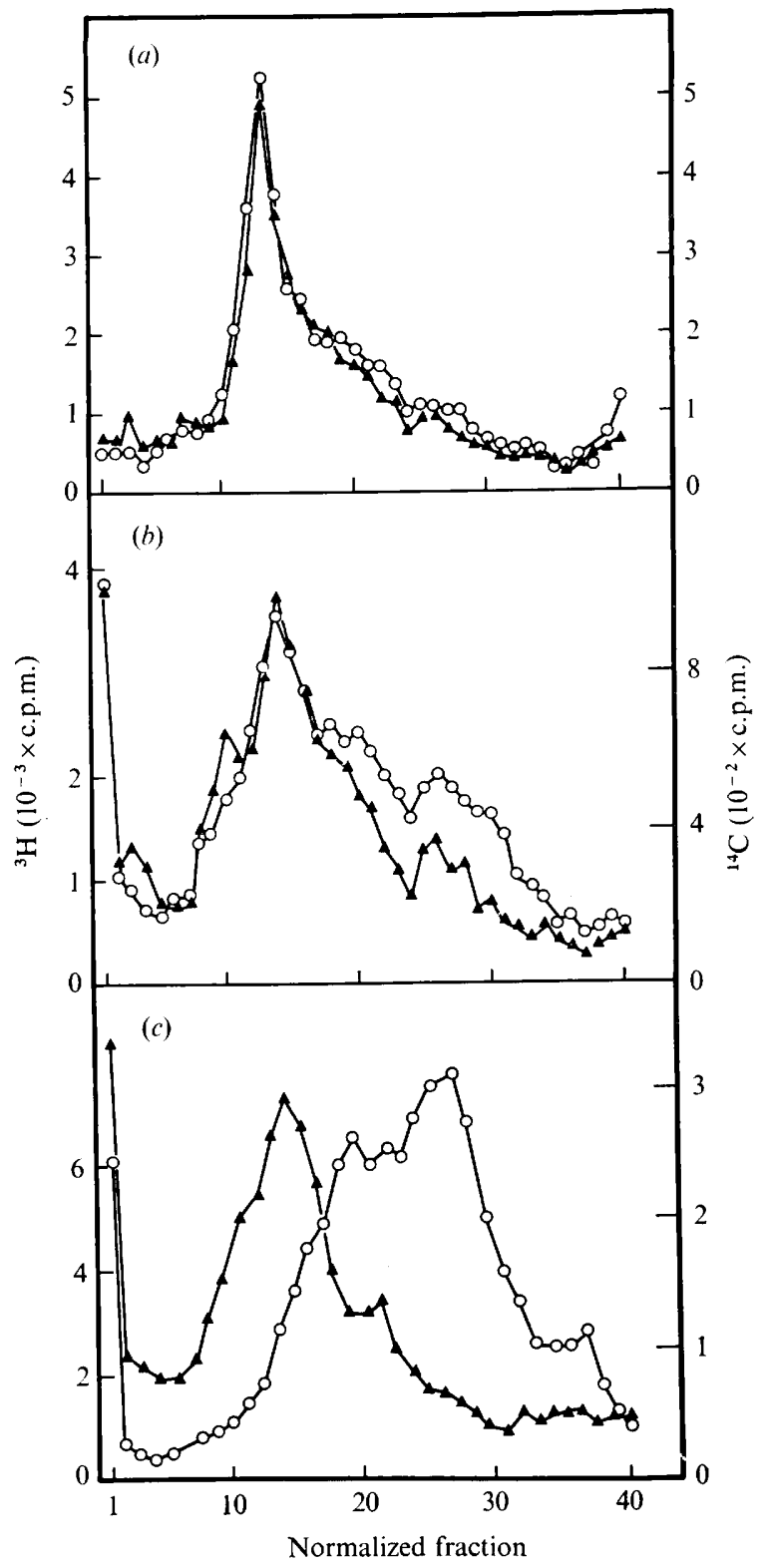

Fig. I. Sedimentation profiles of TAU-bar and ts-7 DNA. [ $\left.{ }^{14} \mathrm{C}\right]$ thymine-labelled TAU-bar and $\left[{ }^{3} \mathrm{H}\right]$ thymine-labelled ts-7 cells were incubated for $20 \mathrm{~min}$ at $(a) 25{ }^{\circ} \mathrm{C},(b) 46{ }^{\circ} \mathrm{C}$, and $(c) 52{ }^{\circ} \mathrm{C}$, and the sedimentation profiles of the DNA were determined. $\boldsymbol{A}$, TAU-bar; 0 , ts- 7 .

these are repaired in TAU-bar but not in ts- 7 as a result of the temperature-sensitive DNA ligase; and secondly, that single strand breaks are induced at all temperatures as a consequence of normal metabolic processes, and are normally repaired through the action of DNA ligase. If the second explanation were true, an equal number of single strand breaks would be expected to appear throughout the temperature range where the ts-7 DNA ligase is inactivated. However, if the first explanation were true, an increasing number of single 
strand breaks would be expected with increasing temperature. The data presented indicate more breakage at $52{ }^{\circ} \mathrm{C}$ than at $46{ }^{\circ} \mathrm{C}$. Accordingly, the simplest explanation of these results is that breakage occurs in both strains upon heating, but in TAU-bar the breaks are repaired through the action of DNA ligase, whereas in ts-7 the temperature-sensitive DNA ligase cannot function to repair single strand breaks at elevated temperatures and hence such breaks remain, leaving ends of polynucleotide strands sensitive to exonuclease digestion.

This work was supported by Public Health Service grant AI-07798 from the National Institute of Allergy and Infectious Diseases.

\section{REFERENCES}

Bridges, B. A., Ashwood-Smith, M. J. \& Munson, R. J. (1969a). Susceptibility of mild-thermal and of ionizing radiation damage to the same recovery mechanisms in Escherichia coli. Bicchemical and Biophysical Research Communications 35, 193-196.

Bridges, B. A., Ashwood-Smith, M. J. \& Munson, R. J. (1969 $b$ ). Correlation of bacterial sensitivities to ionizing radiation and mild heating. Journal of General Microbiology 58, i $15-124$.

Dean, C. \& Pauling, C. (1970). Properties of a deoxyribonucleic acid ligase mutant of Escherichia coli: X-ray sensitivity. Journal of Bacteriology 102, 588-589.

Deutch, C. E. \& Pauling, C. (I97I). Survival and macromolecular synthesis during incubation of Escherichia coli in limiting thymine. Journal of Bacteriology 106, 197-203.

Hanawalt, P. C. (1963). Involvement of synthesis of RNA in thymineless death. Nature, London I98, 286.

Kato, T. \& Kondo, S. (1970). Genetic and molecular characteristics of X-ray sensitive mutants of Escherichia coli defective in repair synthesis. Journal of Bacteriology 104, 87 I-88I.

Matsumoto, S. \& KaGami-Ishi, Y. (1970). The temperature dependence of mortality rate of radiosensitive strains of E. coli and S. cerevisiae. Japanese Journal of Genetics 45, 153-160.

McGrath, R. A. \& Williams, R. W. (I966). Reconstruction in vivo of irradiated Escherichia coli deoxyribonucleic acid: the rejoining of broken pieces. Nature, London 212, 534-535.

PAuling, C. \& HАмm, L. (1968). Properties of a temperature-sensitive radiation-sensitive mutant of Escherichia coli. Proceedings of the National Academy of Sciences of the United States of America 60, I495-I502.

PAuling, C. \& HAMm, L. (1969). Properties of a temperature-sensitive radiation-sensitive mutant of Escherichia coli. II. DNA replication. Prcceedings of the Naticnal Academy of Sciences of the United States of America 64, I 195-I 202.

Sedgwick, S. G. \& BRIDGes, G. A. (1972). Evidence for indirect production of DNA strand scissions during mild heating of Escherichia coli. Journal of General Microbiology 71, 191-193.

Town, C. D., SMITH, K. C. \& KAPLAN, H. S. (197I). Rapid repair of X-ray induced DNA strand breaks in E. coli $\mathrm{K}-\mathrm{I} 2$ and its absence in a mutant lacking DNA polymerase. Science, New York $\mathbf{1 7 2}, 85 \mathrm{I}-853$. 